\title{
Effect of foliar and soil application of potassium on soybean (Glycine max L.)
}

\author{
N.K. Pachlaniya, D.K. Mishra, Jitendra Singh, R.K. Jain and A.K. Shukla
}

Received : 09.02.2018; Revised : 04.05.2018; Accepted : 18.05.2018

MEMBERS OF RESEARCH FORUM:

Corresponding author :

N.K. Pachlaniya, Krishi Vigyan Kendra, Kasturbagram, Indore

(M.P.) India

Email: nitinpachlaniya1@ rediffmail. com

Co-authors :

D.K. Mishra, Jitendra Singh, R. K. Jain and A.K. Shukla, Krishi Vigyan Kendra, Kasturbagram, Indore (M.P.) India

\section{Summary}

The experiments on farmers' field were conducted at Krishi Vigyan Kendra, Indore in nearby two villages during 2016-17 to 2017-18 to assess the impact of soil and foliar application of potassium nutrition on productivity of soybean. On farm trial comprised of three treatments viz., $\mathrm{T}_{1}$ - farmer's practice (18:45:0), $\mathrm{T}_{2}$ - recommended doses of potassium on soil test basis and $\mathrm{T}_{3}$ - foliar application of potassium $(1 \%)$ were taken on the ten farmers field each year. The experimental design was Randomized Block Design with the ten replications in which farmers were taken as the replication. The result indicated that soybean grain yield in the soil application of recommended dose of potassium $\left(\mathrm{T}_{2}\right)$, was significantly superior over foliar application of the potassium $(1 \%)\left(\mathrm{T}_{3}\right)$ and farmer practices $\left(\mathrm{T}_{1}\right)$. The increase in yield was 18.97 per cent in the treatment $\mathrm{T}_{2}$ and 12.20 per cent in treatment $\mathrm{T}_{3}$ over the farmers' practices $\left(\mathrm{T}_{1}\right)$. The soil application of recommended dose of potassium recorded significantly higher average pod per plant and seed index followed by the foliar application of potassium as compared to farmer practice (33.90). Similar trend were also recorded in the gross return, net return and B:C ratio.

Key words : Potassium, Soybean, Foliar spray, Soil application

How to cite this article : Pachlaniya, N.K., Mishra, D.K., Singh, Jitendra, Jain, R.K. and Shukla, A.K. (2018). Effect of foliar and soil application of potassium on soybean (Glycine max L.). Asian J. Soil Sci., 13 (1) : 36-39 : DOI : 10.15740/HAS/AJSS/13.1/36-39. Copyright@ 2018: Hind Agri-Horticultural Society. 